\title{
A meta-analysis of the clinical effectiveness of school scoliosis screening
}

Daniel Y. T. Fong, C. F. Lee, Kenneth M. C. Cheung, Jack C. Y. Cheng, Bobby K. W. Ng, T. P. Lam, K. H. Mak, Paul S. F. Yip, and Keith D. K. Luk

Author affiliations

Department of Nursing Studies, The University of Hong Kong, Pokfulam, Hong Kong SAR China

Dr. Daniel Yee Tak Fong, Ph.D. (e-mail: dytfong@hku.hk)

Mr. Chun Fan Lee, M.Phil. (e-mail: fanlee@hku.hk)

Department of Orthopaedics and Traumatology, The University of Hong Kong,

Pokfulam, Hong Kong SAR, China

Prof. Kenneth Man Chee Cheung, M.D. (e-mail: cheungmc@hku.hk)

Prof. Keith Dip Kei Luk, M.Ch. Orth. (e-mail: hrmoldk@hku.hk)

Department of Orthopaedics and Traumatology, Chinese University of Hong Kong,

Hong Kong SAR, China

Prof. Jack Chun Yiu Cheng, M.D. (e-mail: jackcheng@uab.cuhk.edu.hk)

Dr. Tsz Ping Lam, M.D. (e-mail: tplam@ort.cuhk.edu.hk) 
Department of Orthopaedics and Traumatology, Prince of Wales Hospital, Hong Kong

SAR, China

Dr. Bobby Kin Wah Ng, M.D. (e-mail: bobng@ort.cuhk.edu.hk)

Department of Health, Hong Kong SAR, China

Dr. Kwok Hang Mak, M.Sc. PH (e-mail: drkhmak@dh.gov.hk)

Department of Social Work and Social Administration, The University of Hong Kong,

Hong Kong SAR, China

Prof. Paul Siu Fai Yip, Ph.D. (e-mail: sfpyip@hkucc.hku.hk)

Please send correspondence to:

Keith D. K. Luk

Postal address: Department of Orthopaedics and Traumatology, The University of Hong

Kong, 5/F Professorial block, Queen Mary Hospital, Pokfulam, Hong Kong

Telephone: 852-2855 4254

Fax number: 852-2817 4392

E-mail: hrmoldk@hku.hk 


\section{Financial support}

The work was financially supported by the Central Policy Unit of the Government of the

Hong Kong Special Administrative Region and the Research Grants Council of the

Hong Kong Special Administrative Region, China (Project No.: HKU

7006-PPR-20051). 


\section{ABSTRACT}

Study Design. A meta-analysis that systematically reviewed the evaluation studies of a scoliosis screening program reported in the literature.

Objective. To evaluate the best current evidence on the clinical effectiveness of school screening for adolescent idiopathic scoliosis.

Summary of Background Data. The use of school scoliosis screening is controversial, and its clinical effectiveness has been diversely reported.

Methods. Data sources included three databases, namely PubMed, Google scholar, CINAHL database, and the references from identified reviews and studies. Studies were included if: 1) they adopted a retrospective cohort design; 2) were screened utilizing either the forward bending test (FBT), angle of trunk rotation, or Moiré topography; 3 ) reported results of screening tests and radiographic assessments; 4) screened adolescents only; 5) reported the incidence of curves with a minimum Cobb angle of $10^{\circ}$ or greater; and 6) reported the number of referrals for radiography.

Reviews, comments, case studies, and editorials were excluded.

Results. Thirty-six studies, including thirty-four from the 775 initially identified studies and two from the references, met the selection criteria. The pooled referral rate for radiography was $5.0 \%$, and the pooled positive predictive value (PPV) for detecting 
curves $\geq 10^{\circ}$, curves $\geq 20^{\circ}$, and treatment were $28.0 \%, 5.6 \%$, and $2.6 \%$, respectively.

There was substantial heterogeneity across studies. Meta-regression showed that programs using the FBT alone reported a higher referral rate (odds ratio $[\mathrm{OR}]=2.91$ ) and lower PPV for curves $\geq 10^{\circ}(\mathrm{OR}=0.49)$ and curves $\geq 20^{\circ}(\mathrm{OR}=0.34)$ than programs using other tests. Only one small study followed students until skeletal maturity and reported the sensitivity of screening; however, the specificity was not reported. No severe publication bias was noted.

Conclusions. The use of the FBT alone in school scoliosis screening is insufficient. We need large, retrospective cohort studies with sufficient follow-up to properly assess the clinical effectiveness of school scoliosis screening.

Key Words: adolescent idiopathic scoliosis, school screening program, meta-analysis, retrospective cohort studies. 


\section{Key Points}

- Studies that reported the clinical effectiveness of a school screening program for adolescent idiopathic scoliosis were systematically reviewed. Finally, thirty-six studies were included in a meta-analysis.

- The pooled referral rate for radiography was $5.0 \%$, and the pooled positive predictive values (PPV) for detecting curves $\geq 10^{\circ}$, curves $\geq 20^{\circ}$, and treatment were $28.0 \%, 5.6 \%$, and $2.6 \%$, respectively.

- Programs that used the forward bending test as the only screening tool had a higher referral rate and a lower precision in detecting scoliotic curves.

- Only one small study followed the screened children until their skeletal maturity, and reported the sensitivity of the screening program. 


\section{INTRODUCTION}

Untreated cases of adolescent idiopathic scoliosis (AIS) may progress, and severe cases are at increased risk for various morbidity problems and mortality. ${ }^{1}$ Therefore, most physicians are committed to the early detection of scoliosis and, hence, recommend school scoliosis screening. ${ }^{2}$ However, the use of scoliosis screening remains debatable. $^{3,4}$ The main concerns of school scoliosis screening include unnecessary referrals and excessive costs. ${ }^{3,5}$ Several reviews have been conducted, but none of these has been systematic. ${ }^{2,3,6-9}$

Different designs have been adopted to evaluate school scoliosis screening. The most recent design is a gender- and age-matched case-control study which concluded that exposure to screening was not significantly different between operated AIS patients and normal subjects. ${ }^{10}$ The case-control design generally suffers from confounding factors, and comparing exposure to screening appears to be equivalent to comparing the participation rate rather than the screening accuracy. Indeed, case-control studies are considered as only level III studies. ${ }^{11}$ Furthermore, retrospective studies focusing on treated AIS patients found a significantly smaller Cobb angle at detection or a lower

operation rate in screened than otherwise detected patients. ${ }^{12-14}$ Unfortunately, such analyses would likely over-estimate the screening effectiveness due to 1) lead-time bias when AIS is detected by screening prior to the clinical presentation of spinal deformity 
that deserves clinical follow-up or treatment and 2) length bias when slowly progressive curves are more likely to be detected by screening than highly progressive curves. ${ }^{15}$ There has also been time series studies reporting the number of patients with AIS identified or treated at defined time periods. ${ }^{16-19}$ Such a design, however, cannot determine a referral rate for radiography or the positive predictive values that assess the clinical effectiveness. To date, only one randomized controlled trial (RCT) has assessed the accuracy of screening for AIS. ${ }^{20}$ However, the study recruited only 15 children, and included no follow-up examination of the children. Indeed, a long follow-up of adolescents until skeletal maturity would be desirable because progression is likely to occur during adolescence. However, this follow-up would mean a period of almost ten years; this procedure may be unethical for children who are not allocated for screening. Additionally, other factors, such as the screeners' experience, use of other screening tests, and the children's participation, would not be considered in an RCT that focuses on efficacy rather than effectiveness. While RCT is a level I design that has the most robust design against various biases, it is not adequate for assessing the clinical effectiveness of school scoliosis screening in a community-based program.

Most other evaluations of school scoliosis screening have been performed in retrospective cohort studies in which a defined cohort of students was followed. Such studies have been performed primarily in a community-based setting, and the design 
allows different measures of clinical effectiveness to be calculated. Therefore, this

level II design is preferable for evaluating school scoliosis screening. ${ }^{11}$ However, these studies vary in screening results and conclusions. Therefore, we aimed to

systematically review the available retrospective cohort studies to assess the clinical effectiveness of school screening for AIS.

\section{METHODS}

Search strategy

Relevant studies were queried using the keywords "screening" and "scoliosis" in the title and abstract fields in PubMed, and then in the title field of Google Scholar under three subject areas: (1) Biology, Life Sciences, and Environmental Science; (2) Medicine, Pharmacology, and Veterinary Science; and (3) Social Sciences, Arts, and Humanities, and finally in the title, abstract, full text, and text word fields of the CINAHL database. Titles and abstracts were screened for potential studies, and full papers were located and read to identify eligible studies. The reference lists from all identified studies and reviews were also examined for additional studies. The search was performed by the first two authors, and the first author, DYTF, has prior experience in systematic review and meta-analysis. 
Study selection

Studies were included if they (1) adopted a retrospective cohort design; (2) considered a screening program that utilized either the forward bending test (FBT), angle of trunk rotation (ATR), or Moiré topography; (3) reported results of screening tests and radiographic assessments; (4) screened adolescents only; (5) reported the incidence of curves with a minimum Cobb angle of $10^{\circ}$ or greater; and (6) reported the number of referrals for radiography. Reviews, comments, case studies, and editorials were excluded.

Data extraction and meta-analysis

Data were extracted independently by two of the authors using a standardized Excel template. These data included (1) details of the screening, including tests performed, referral criteria, personnel, and period examined; (2) prevalence, calculated for a defined curvature and treatment (brace or surgery) based on the number of screened students; (3) sensitivity, calculated as the proportions of subjects who had a defined curvature and who received treatment detected by screening; (4) specificity, calculated as the proportions of students who did not have a defined curvature and who did not receive treatment correctly identified by screening; and (5) positive predictive value (PPV), calculated as the proportions of students referred for radiography who had a defined 
curvature and who received treatment. These data, when not reported, were calculated from available data if possible. Figures reported in studies were also verified when reliable data were available. Prevalence, sensitivity, and PPV were calculated for curvatures $\geq 10^{\circ}$ and $\geq 20^{\circ}$. Note that the negative predictive value (NPV) is often close to $100 \%$ in school scoliosis screenings, due to the low prevalence of AIS. Additionally, there was no restriction on the written language of studies; assistance from a professional translation company was sought when there was difficulty understanding the study contents.

The pooled estimates for the prevalence and PPV were obtained by random effects using the exact method based on the binomial distribution. ${ }^{21}$ The method is more robust than the commonly used approximation method by DerSimonian and Laird. ${ }^{21,22}$ A heterogeneity test was performed by testing for the significance of the between-study variance. The proportion of total variation in study estimates that is due to heterogeneity, $\mathrm{I}^{2}$, was calculated as a measure of heterogeneity. ${ }^{23}$ Sources of heterogeneity were first explored by a univariable meta-regression on study-specific characteristics, including whether the study examined a routine screening program, whether the study involved screeners specialized in orthopedics, whether the FBT was the only screening test, whether the FBT and ATR were used, and the study's year of publication and size. The study size was classified as large if it was no smaller than the 
median size and small otherwise. Then, a multivariable meta-regression with a forward selection on the same set of variables was performed. The results were used to guide a subgroup analysis. Publication bias was examined by a funnel plot, which plots the logit of the estimates against their precision, taken as $1 /$ standard error. $^{24}$ The meta-analysis was performed with Statistical Analysis System (SAS) Version 9.2. ${ }^{25}$

\section{RESULTS}

Identification of studies

A PubMed search performed on January 16, 2008 resulted in 350 citations. Titles and abstracts were screened, and 94 potential studies were identified. After reading the full papers, 27 articles were retained. Google Scholar was searched on September 11, 2008 and yielded 348 citations. After screening titles, abstracts, and full papers where necessary, six eligible studies that were not identified in PubMed were found. The CINAHL database was searched on November 5, 2008, resulting in 77 citations; one study not covered by the above two databases was recognized as eligible. The reference of these articles were read, and two additional studies were found. Finally, 36 retrospective cohort studies (twenty-seven in English, two in Hebrew, two in Simplified Chinese, two in Japanese, one in Danish, one in Spanish, and one in Bulgarian) were reviewed. 
The identified studies were published from 17 countries between 1977 and 2005 .

Details of their screening programs are listed in Table 1. The studies took a median of 3.5 years (range $=0$ to 13 years) before they were published after data collection. Ten studies (28\%) evaluated a routine screening program, and twenty-four (67\%) performed screening as a research or pilot program. The nature of the screening program in the other two studies was not determined due to insufficient information. The three studies that evaluated a routine screening program in Crete, Greece, Rochester, US, and Singapore reported participation rates of $88 \%, 76 \%$, and $48 \%$ respectively. A total of $23(64 \%), 5(14 \%)$, and $7(19 \%)$ studies concluded that school scoliosis screening was clinically effective, clinically ineffective, or of uncertain effect, respectively (note that one study had insufficient details).

Screening tests

Twenty-three (64\%) studies used the FBT as the only screening test. Eight (22\%) studies additionally measured the ATR, and two (6\%) further used Moiré topography. One other study used the FBT and Moiré topography, and two others used Moiré topography and low-dose roentgenography. For the eight studies that used the ATR for referring students to radiography, measures from $4^{\circ}$ to $15^{\circ}$ were used as the minimum criterion. Of the four studies that used Moiré topography, three reported a criterion of 
$5 \mathrm{~mm}$ or 2 lines used; the other study did not report the criterion.

Among the 34 studies that mentioned the background of the screeners, $13(36 \%)$ involved nurses, with one (3\%) had a specialization in orthopedics. Other screeners included orthopedists (11), physicians (8), physical therapists (4), pediatricians (2), physical education teachers (1), residents or medical students (3), school medical workers (1), social workers (1), and trained lay volunteers (2). A total of $13(36 \%)$ studies had screeners specialized in orthopedics.

Students screened

The median number of students screened was 5,128 (range $=161$ to 968,424). An eligible age range for screening was specified in $30(83 \%)$ studies. Five studies screened students as early as 6 years old, but most studies (eight) started screening students when they were 10 years old. Thirty-three (92\%) studies screened both boys and girls, and the remaining three studies screened girls only.

Follow-up information

Sixteen (44\%) studies did not provide follow-up information for the screened students, and fifteen (42\%) only followed students with detected AIS. Four studies had taken follow-up information for 1 to 3 years on the screened students. Only one study 
screening 2,242 children had follow-up information from screened students through

skeletal maturity. ${ }^{5}$ Indeed, this was also the only study that reported the sensitivity as $64.0 \%(95 \%$ confidence interval $[\mathrm{CI}]=45.2 \%$ to $82.8 \%)$ for detecting curves $\geq 20^{\circ}$ and $55.6 \%(95 \% \mathrm{CI}=23.1 \%$ to $88.0 \%)$ for treatment. No studies reported the specificity of school scoliosis screening.

Meta-analysis

The pooled estimates are shown in Table 2. Between-study heterogeneity was significant, with an $\mathrm{I}^{2}$ greater than $90 \%$. Both univariable and multivariable meta-regression had consistent conclusions regarding the significance of different potential sources. Hence, only the results from multivariable meta-regression are shown in Table 2. More recently published studies demonstrated a 3\% lower prevalence of curves $\geq 10^{\circ}$ for each later year. Large studies demonstrated an $84 \%$ lower in the odds of treatment prevalence and $70 \%$ lower in the odds of PPV for treatment. However, the latter difference was marginally insignificant $(p=0.074)$, possibly due to the small number of studies (13) reporting treatment information. We also noted that fewer students were referred by large studies than by small studies $(\mathrm{OR}=$ $0.49,95 \% \mathrm{CI}=0.25$ to $0.96, \mathrm{p}=0.037)$, but this effect became insignificant after accounting for the screening tests. On the other hand, studies that only used the FBT 
for screening had $191 \%$ higher in the odds of referral rate for radiography, and $51 \%$ and $66 \%$ lower in the odds of PPV for curves $\geq 10^{\circ}$ and $\geq 20^{\circ}$, respectively. The forest plots and pooled estimates for the corresponding subgroups are shown in Figures 1-3. Study heterogeneity remained significant for the referral rate and PPV for curves $\geq 10^{\circ}$ and $\geq 20^{\circ}$ in all subgroups.

The funnel plots did not indicate severe publication bias. However, the study conducted in Chiba, Japan, may have introduced publication bias in the referral rate and PPV for curves $\geq 20^{\circ}$. Moreover, another study in Japan was an outlier in terms of its high PPV for curves $\geq 20^{\circ}$ (Figure 3(b)). Indeed, these two studies were the only studies that used low-dose roentgenography for screening; this method is more precise and results in a low referral rate and high PPV for detecting curves. Removal of these studies did not substantially alter the estimates and conclusions, except that the pooled estimate of the PPV for detecting curves $\geq 20^{\circ}$ reduced to $7.6 \%(95 \% \mathrm{CI}=2.91 \%$ to 12.2\%; heterogeneity: $\mathrm{p}=0.087, \mathrm{I}^{2}=95.8 \%$ ) for studies using the FBT only.

\section{DISCUSSION}

This study was the first meta-analysis that estimated the clinical effectiveness of school scoliosis screening. The pooled PPVs for detecting curves $\geq 10^{\circ}$ and $\geq 20^{\circ}$ and treatment were low, which indicates that school scoliosis screening may not have been 
performed effectively. However, there was considerable heterogeneity across studies with high $\mathrm{I}^{2}$ and concerns regarding study design. Conclusions made solely based on the pooled estimates may be inadequate.

The meta-regression showed that the use of the FBT alone resulted in a higher referral rate (7.2\% vs. $2.6 \%)$ and lower PPV for curves $\geq 10^{\circ}(23.2 \%$ vs. $38.0 \%)$ and $\geq 20^{\circ}(3.5 \%$ vs. $11.0 \%)$. However, there was no evidence that the use of the FBT alone influenced the detection of students requiring treatment, which may be due to the fact that only 13 studies (38\%) reported treatment details. The use of either the ATR, Moiré topography, low-dose roentgenography, or a combination improved the accuracy of referral, but the evidence was not sufficient to determine if any of these would produce additional benefit. Although the FBT is the most common method for scoliosis screening, it is rather subjective. The evaluation quality may vary with the screeners' experience and qualification. Only two studies were designed to evaluate the use of the FBT for AIS screening, and they reported opposing conclusions. ${ }^{26-28}$ Nevertheless, because the FBT is simple and inexpensive, we do not suggest excluding it but recommend the use of additional tests.

Studies published earlier reported a higher prevalence for curves $\geq 10^{\circ}$ than more recently published ones. This difference may be due to the age at which children were screened. Children aged between 10 and 14 years are most likely to develop scoliosis. 
In fact, more recent studies tend to screen more children aged outside of this age range.

As a result, the prevalence was lowered by the inclusion of these lower risk children in the cohort.

Large studies reported a lower prevalence of treatment $(0.07 \%$ vs. $0.43 \%$ in small studies). Indeed, although the effect became insignificant after considering the use of screening tests, small studies referred subjects more frequently than large studies $(\mathrm{p}=$ 0.037). This practice may result in higher prevalence estimates among small studies. Moreover, routine screening programs that covered a wider scope of a population were more frequently included in large studies (44\%) than in small studies (13\%).

Nevertheless, there was weak evidence that small studies more accurately identified cases requiring treatment $(\mathrm{p}=0.074)$. However, this finding was based on only 13 (38\%) studies that reported treatment details. As no similar effect on the PPV for detecting curves $\geq 10^{\circ}$ or $\geq 20^{\circ}$ was observed, this effect remains preliminary.

The $\mathrm{I}^{2}$ value assesses the between-study variability relative to the within-study variability. The median number of students screened was 5,128, with $30(83 \%)$ studies screened over 1,000 students and 14 (39\%) screened more than 10,000. Therefore, within-study variability was small in most studies, and a small difference across studies may result in a high $\mathrm{I}^{2}$. This is evident from the generally smaller $\mathrm{I}^{2}$ and larger $\mathrm{p}$-value for testing heterogeneity in small studies. Nevertheless, there may also be other 
unidentified sources of heterogeneity besides the use of the FBT alone. For example, as AIS is more common in girls than in boys, screening girls only may result in a higher accuracy. However, only three studies screened girls alone, which are likely not representative for assessing the effect of screening girls only.

Only $13(36 \%)$ studies reported treatment outcomes. Two of these studies did not have follow-up data but reported instead the treatments administered by the time AIS patients were confirmed. Two other studies followed patients for 3 years at most. However, AIS is likely to progress during adolescence. Insufficient follow-up may under-estimate the detection rate for treated cases. Absent or insufficient follow-up information for all screened students precludes the reliable determination of the number of AIS patients identified during adolescence, and it is from this number that the sensitivity and specificity are obtained. Clinicians are often interested in predictive values, which are however influenced by the disease prevalence. Therefore, measures of sensitivity and specificity that do not depend on disease prevalence are often preferable. To date, only one study estimated the sensitivity; however, the precision was low, with an error of $32 \% .^{5}$ Hence, there was a severe lack of large studies that followed students until skeletal maturity.

Despite our efforts to include all studies without written language restrictions, some studies may not have been identified. However, our results based on 36 studies are not 
likely change, especially because there was no clear indication of publication bias.

In conclusion, there was substantial heterogeneity across studies due to the use of different screening tests and different study sizes. The use of the FBT alone in school scoliosis screening is insufficient. To properly assess the clinical effectiveness of school scoliosis screening, we need large retrospective cohort studies with students

followed by skeletal maturity. This assessment could be facilitated by the continuation of school scoliosis screening programs. 


\section{REFERENCES}

1. Weinstein SL, Dolan LA, Spratt KF, Peterson KK, Spoonamore MJ, Ponseti IV. Health and function of patients with untreated idiopathic scoliosis: a 50-year natural history study. JAMA. Feb 5 2003;289(5):559-567.

2. Grivas TB, Wade MH, Negrini S, et al. SOSORT consensus paper: school screening for scoliosis. Where are we today? Scoliosis. 2007;2:17.

3. Richards BS, Vitale MG. Screening for idiopathic scoliosis in adolescents. An information statement. J Bone Joint Surg Am. Jan 2008;90(1):195-198.

4. Karachalios T, Roidis N, Papagelopoulos PJ, Karachalios GG. The efficacy of school screening for scoliosis. Orthopedics. Apr 2000;23(4):386-391.

5. Yawn BP, Yawn RA, Hodge D, et al. A population-based study of school scoliosis screening. JAMA. Oct 20 1999;282(15):1427-1432.

6. Karachalios T, Roidis N, Papagelopoulos PJ, Karachalios GG. The efficacy of school screening for scoliosis. Orthopedics. Apr 2000;23(4):386-391; quiz 392-383.

7. USPSTF. Screening for adolescent idiopathic scoliosis. Review article. US Preventive Services Task Force. JAMA. May 26 1993;269(20):2667-2672.

8. Morrissy RT. School screening for scoliosis. Spine. Dec 15 1999;24(24):2584-2591. 
9. Leaver JM, Alvik A, Warren MD. Prescriptive screening for adolescent idiopathic scoliosis: a review of the evidence. Int J Epidemiol. Jun 1982;11(2):101-111.

10. Bunge EM, Juttmann RE, van Biezen FC, et al. Estimating the effectiveness of screening for scoliosis: a case-control study. Pediatrics. Jan 2008;121(1):9-14.

11. Obremskey WT, Pappas N, Attallah-Wasif E, Tornetta P, 3rd, Bhandari M. Level of evidence in orthopaedic journals. J Bone Joint Surg Am. Dec 2005;87(12):2632-2638.

12. Bunge EM, Juttmann RE, de Koning HJ. Screening for scoliosis: do we have indications for effectiveness? J Med Screen. 2006;13(1):29-33.

13. Montgomery F, Willner S. Screening for idiopathic scoliosis. Comparison of 90 cases shows less surgery by early diagnosis. Acta Orthop Scand. Aug 1993;64(4):456-458.

14. Ferris B, Edgar M, Leyshon A. Screening for scoliosis. Acta Orthop Scand. Aug 1988;59(4):417-418.

15. Pelikan S, Moskowitz M. Effects of lead time, length bias, and false-negative assurance on screening for breast cancer. Cancer. Mar 15 1993;71(6):1998-2005.

16. Torell G, Nordwall A, Nachemson A. The changing pattern of scoliosis treatment due to effective screening. J Bone Joint Surg Am. Mar 1981;63(3):337-341. 
17. Montgomery F, Willner S. The natural history of idiopathic scoliosis. Incidence of treatment in 15 cohorts of children born between 1963 and 1977. Spine. Apr 1 1997;22(7):772-774.

18. Willner S. A comparative study of the efficiency of different types of school screening for scoliosis. Acta Orthop Scand. Oct 1982;53(5):769-774.

19. Koga Y. [The result of the author's screening system of scoliosis in elementary and junior-high schools]. Nippon Seikeigeka Gakkai Zasshi. Jan 1986;60(1):61-71.

20. Viviani GR, Budgell L, Dok C, Tugwell P. Assessment of accuracy of the scoliosis school screening examination. Am J Public Health. May $1984 ; 74(5): 497-498$.

21. Hamza TH, van Houwelingen HC, Stijnen T. The binomial distribution of meta-analysis was preferred to model within-study variability. J Clin Epidemiol. Jan 2008;61(1):41-51.

22. DerSimonian R, Laird N. Meta-analysis in clinical trials. Control Clin Trials. Sep 1986;7(3):177-188.

23. Higgins JP, Thompson SG. Quantifying heterogeneity in a meta-analysis. Stat Med. Jun 15 2002;21(11):1539-1558.

24. Sutton AJ, Duval SJ, Tweedie RL, Abrams KR, Jones DR. Empirical assessment 
of effect of publication bias on meta-analyses. BMJ. Jun 10

2000;320(7249):1574-1577.

25. Clark V, SAS Institute. SAS/STAT® 9.1 user's guide. Cary, N.C.: SAS Institute; 2004.

26. Cote P, Kreitz BG, Cassidy JD, Dzus AK, Martel J. A study of the diagnostic accuracy and reliability of the Scoliometer and Adam's forward bend test. Spine. Apr 1 1998;23(7):796-802; discussion 803.

27. Karachalios T, Sofianos J, Roidis N, Sapkas G, Korres D, Nikolopoulos K. Ten-year follow-up evaluation of a school screening program for scoliosis. Is the forward-bending test an accurate diagnostic criterion for the screening of scoliosis? Spine. Nov 15 1999;24(22):2318-2324.

28. Simpson R, Gemmell H. Accuracy of spinal orthopaedic tests: a systematic review. Chiropr Osteopat. 2006;14:26.

29. Newman DC, DeWald RL. School screening for scoliosis. IMJ Ill Med J. Jan $1977 ; 151(1): 31-34$

30. O'Brien JP, Van Akkerveeken PF. School screening for scoliosis: results of a pilot study. Practitioner. Nov 1977;219(1313):739-742.

31. Rogala EJ, Drummond DS, Gurr J. Scoliosis: incidence and natural history. A prospective epidemiological study. J Bone Joint Surg Am. Mar 
1978;60(2):173-176.

32. Smyrnis PN, Valavanis J, Alexopoulos A, Siderakis G, Giannestras NJ. School screening for scoliosis in Athens. J Bone Joint Surg Br. May $1979 ; 61-B(2): 215-217$.

33. Dickson RA, Stamper P, Sharp AM, Harker P. School screening for scoliosis: cohort study of clinical course. BMJ. Jul 26 1980;281(6235):265-267.

34. Gore DR, Passehl R, Sepic S, Dalton A. Scoliosis screening: results of a community project. Pediatrics. Feb 1981;67(2):196-200.

35. Randall FM, Denton TE. Scoliosis screening: a school survey. Ala J Med Sci. Oct $1983 ; 20(4): 395-396$.

36. Morais T, Bernier M, Turcotte F. Age- and sex-specific prevalence of scoliosis and the value of school screening programs. Am J Public Health. Dec 1985;75(12):1377-1380.

37. Pin LH, Mo LY, Lin L, et al. Early diagnosis of scoliosis based on school-screening. J Bone Joint Surg Am. Oct 1985;67(8):1202-1205.

38. Chan A, Moller J, Vimpani G, Paterson D, Southwood R, Sutherland A. The case for scoliosis screening in Australian adolescents. Med J Aust. Oct 20 $1986 ; 145(8): 379-383$.

39. Keret D, Fishman J, Lucian M. [Screening for scoliosis in Haifa schools]. 
Harefuah. Jun 1 1986;110(11):565-568.

40. Shannak A. School screening for scoliosis in Amman. Jordan Medical Journal. $1986 ; 21(2): 219-227$.

41. Fazey G. Screening of adolescent school children for idiopathic scoliosis. Nursing Times. 1988;8(13):58.

42. Ohtsuka Y, Yamagata M, Arai S, Kitahara H, Minami S. School screening for scoliosis by the Chiba University Medical School screening program. Results of 1.24 million students over an 8-year period. Spine. Nov 1988;13(11):1251-1257.

43. Zhang GP, Li ZR, Wei XR, Cao YL, Cui QL. Screening for scoliosis among school children in Beijing. Chin Med J (Engl). Feb 1988;101(2):151-154.

44. Juma AHA, Mursal AM, Mangoud AM, Ibrahim MA. Adolescent Idiopathic Scoliosis in School-Children. Saudi Medical Journal. May 1989;10(3):213-215.

45. Al-Turaiki MH, Al-Falahi LA, Eddin MFS, K. KM. School screening for scoliosis in Riyadh. Saudi Medical Journal. 1994;15(4):277-280.

46. Hansen TB. [Adolescent idiopathic scoliosis among girls in the Herning region. A follow-up of girls with adolescent idiopathic scoliosis found in an earlier screening at school]. Ugeskr Laeger. Aug 29 1994;156(35):4979-4982.

47. Goldberg CJ, Dowling FE, Fogarty EE, Moore DP. School scoliosis screening and the United States Preventive Services Task Force. An examination of 
long-term results. Spine. Jun 15 1995;20(12):1368-1374.

48. Ma X, Zhao B, Lin QK. [Investigation on scoliosis incidence among 24,130

school children]. Zhonghua Liu Xing Bing Xue Za Zhi. Apr 1995;16(2):109-110.

49. David R, Jamal A, Soudry M. [Screening for scoliosis in western Galilee

schools]. Harefuah. Mar 1 1996;130(5):297-300, 358.

50. Pruijs JE, van der Meer R, Hageman MA, Keessen W, van Wieringen JC. The benefits of school screening for scoliosis in the central part of The Netherlands.

Eur Spine J. 1996;5(6):374-379.

51. Stirling AJ, Howel D, Millner PA, Sadiq S, Sharples D, Dickson RA. Late-onset idiopathic scoliosis in children six to fourteen years old. A cross-sectional prevalence study. J Bone Joint Surg Am. Sep 1996;78(9):1330-1336.

52. Tanchev P, Dikov D, Dzherov A, et al. School screening for scoliosis in Sofia: An analysis of screening results of 4800 students. Orthop Trauma. 1996;33(2):69-73.

53. Wang YP, Ye QB, Wu B. [Result on the screening of scoliosis among school students in Beijing area]. Zhonghua Liu Xing Bing Xue Za Zhi. Jun 1996;17(3):160-162.

54. Keskin D, Bodur H, Acar F, Boyacigil S, Keskin G, Yücel M. School screening for scoliosis in Turkish children. European Journal of Physical Medicine \& 
Rehabilitation. 1997;7(2):42-45.

55. Koukourakis I, Giaourakis G, Kouvidis G, Kivernitakis E, Blazos J, Koukourakis M. Screening school children for scoliosis on the island of Crete. J Spinal Disord.

Dec 1997;10(6):527-531.

56. Soucacos PN, Soucacos PK, Zacharis KC, Beris AE, Xenakis TA.

School-screening for scoliosis. A prospective epidemiological study in northwestern and central Greece. J Bone Joint Surg Am. Oct 1997;79(10):1498-1503.

57. Minehisa K, Matunaga Y, Tuyuguti A, et al. School-screening for scoliosis. Rigakuryoho Kagaku. 1999;14(2):69-72.

58. Motohashi R, Mori I, Kurosawa Y, et al. Study on an efficient school screening system for scoliosis. Yobo Igaku Janaru. 1999(346):13-17.

59. Redondo Granado MJ, Arnillas Gomez P, Fernandez Alonso C. [Screening for adolescent idiopathic scoliosis: is current knowledge sufficient to support its use?]. An Esp Pediatr. Feb 1999;50(2):129-133.

60. Grivas TB, Samelis P, Polyzois BD, Giourelis B, Polyzois D. School screening in the heavily industrialized area--Is there any role of industrial environmental factors in idiopathic scoliosis prevalence? Stud Health Technol Inform. 2002;91:76-80. 
61. Nussinovitch M, Finkelstein Y, Amir J, Greenbaum E, Volovitz B. Adolescent screening for orthopedic problems in high school. Public Health. Jan 2002;116(1):30-32.

62. Velezis MJ, Sturm PF, Cobey J. Scoliosis screening revisited: findings from the District of Columbia. J Pediatr Orthop. Nov-Dec 2002;22(6):788-791.

63. Wong HK, Hui JH, Rajan U, Chia HP. Idiopathic scoliosis in Singapore schoolchildren: a prevalence study 15 years into the screening program. Spine. May 15 2005;30(10):1188-1196. 
Table 1. Characteristics of school scoliosis screening programs*

\begin{tabular}{|c|c|c|c|c|c|c|c|c|c|}
\hline & $\begin{array}{l}\text { City/Country } \\
\text { (Publication year) }\end{array}$ & $\begin{array}{l}\text { Routine } \\
\text { screening } \\
\text { program? }\end{array}$ & Screening tests & Screeners & $\begin{array}{l}\text { Screening } \\
\text { age }\end{array}$ & $\begin{array}{l}\text { Screening } \\
\text { period }\end{array}$ & Follow-up & $\begin{array}{l}\text { Total screened } \\
\text { (Boys/Girls) }\end{array}$ & $\begin{array}{l}\text { Clinical } \\
\text { effectiveness } \\
\text { concluded? }\end{array}$ \\
\hline 1. & $\begin{array}{l}\text { Chicago/US } \\
\text { (1977) }\end{array}$ & No & FBT & $\begin{array}{l}\text { Physical therapists, } \\
\text { orthopedic nurses }\end{array}$ & NA & NA & None & $\begin{array}{c}861 \\
(372 / 469) \\
\end{array}$ & Yes \\
\hline 2. & $\begin{array}{l}\text { Oswestry/England }{ }^{2} \\
\text { (1977) }\end{array}$ & No & FBT & School nurses & $11-14$ & NA & None & 869 & Yes \\
\hline 3. & $\begin{array}{l}\text { Montreal/Canada }{ }^{3} \\
(1978)\end{array}$ & Yes & FBT & $\begin{array}{l}\text { School nurses, } \\
\text { physicians }\end{array}$ & $12-14$ & 1974-1976 & $\begin{array}{l}\text { On cases only } \\
(2 \text { years })\end{array}$ & $\begin{array}{c}26,947 \\
(13,473 / 13,474) \dagger\end{array}$ & Yes \\
\hline 4. & $\begin{array}{l}\text { Athens }{ }^{4} \\
(1979)\end{array}$ & No & FBT & Orthopedists & NA & 1974 & $\begin{array}{l}\text { On some } \\
\text { cases only } \\
\text { (1-2 years) }\end{array}$ & $\begin{array}{c}3,494 \\
(1,874 / 1,620)\end{array}$ & No opinion \\
\hline 5. & $\begin{array}{l}\text { Oxford/England }{ }^{5} \\
(1980)\end{array}$ & No & FBT & $\begin{array}{l}\text { A senior } \\
\text { physiotherapist }\end{array}$ & $13-14$ & NA & On cases only & 1,764 & Yes \\
\hline 6. & $\begin{array}{l}\text { Wisconsin/ } \mathrm{US}^{6} \\
\text { (1981) }\end{array}$ & Yes & FBT & $\begin{array}{l}\text { Trained lay } \\
\text { volunteers, physical } \\
\text { therapists, nurses }\end{array}$ & NA & $1973-1977$ & On cases only & $\begin{array}{c}8,393 \\
(751 / 7,642)\end{array}$ & Yes \\
\hline 7. & $\begin{array}{l}\text { Alabama/US } \\
(1983)\end{array}$ & No & FBT & Orthopedists & NA & NA & On cases only & 561 & Yes \\
\hline 8. & $\begin{array}{l}\text { Quebec City/ } \\
\text { Canada }^{8} \\
(1985)\end{array}$ & No & FBT & Trained nurses & $8-15$ & $1977-1978$ & On cases only & $\begin{array}{c}29,195 \\
(14,506 / 14,689)\end{array}$ & No \\
\hline 9. & $\begin{array}{l}\text { Changsha and Lian } \\
\text { Yuan/China9 } \\
(1985)\end{array}$ & No & FBT & Orthopedic surgeons & $6-15$ & 1983 & $\begin{array}{l}\text { On some } \\
\text { cases only }\end{array}$ & $\begin{array}{c}8,165 \\
(4,202 / 3,963)\end{array}$ & Yes \\
\hline 10. & $\begin{array}{l}\text { Adelaide/Australia } \\
\text { (1986) }\end{array}$ & No & FBT & A nurse & $14-16$ & $1982-1983$ & None & $\begin{array}{c}3,660 \\
(1,945 / 1,715) \dagger\end{array}$ & Yes \\
\hline
\end{tabular}


Table 1. Characteristics of school scoliosis screening programs (cont)*

\begin{tabular}{|c|c|c|c|c|c|c|c|c|}
\hline $\begin{array}{l}\text { 11. Haifa/Israel }{ }^{11} \\
(1986)\end{array}$ & No & FBT & An orthopedist & $10-12$ & 1984-1985 & On cases only & $\begin{array}{c}2,369 \\
(1,154 / 1,215) \\
\end{array}$ & NA \\
\hline $\begin{array}{l}\text { 12. Amman/Jordan }{ }^{12} \\
(1986)\end{array}$ & No & FBT & Doctors & $11-16$ & $\begin{array}{l}\text { Feb-May } \\
1982\end{array}$ & None & 10,287 & Yes \\
\hline $\begin{array}{l}\text { 13. England }{ }^{13} \\
\text { (1988) }\end{array}$ & No & FBT/ATR & NA & $11-15$ & 1984 & None & 5,350 & No opinion \\
\hline $\begin{array}{l}\text { 14. Chiba/Japan }{ }^{14} \\
\text { (1988) }\end{array}$ & Yes & $\begin{array}{l}\text { Moiré } \geq 5 \mathrm{~mm}, \\
\text { Low-dose } \\
\text { roentgenography }\end{array}$ & $\begin{array}{l}\text { Objectively } \\
\text { measured (screeners } \\
\text { not mentioned) }\end{array}$ & $10-14$ & 1979-1986 & $\begin{array}{l}\text { Varied from } \\
\text { none till left } \\
\text { school }\end{array}$ & 968,424 & Yes \\
\hline $\begin{array}{l}\text { 15. Beijing/China }{ }^{15} \\
\text { (1988) }\end{array}$ & No & $\begin{array}{l}\mathrm{FBT} / \mathrm{ATR} \geq 3^{\circ} \\
\text { Moiré } \geq 5 \mathrm{~mm}\end{array}$ & $\begin{array}{l}\text { School medical } \\
\text { workers, orthopedists }\end{array}$ & $7-15$ & $1985-1986$ & On cases only & $\begin{array}{c}20,418 \\
(10,283 / 10,135)\end{array}$ & Yes \\
\hline $\begin{array}{l}\text { 16. Jeddah/Saudi } \\
\text { Arabia }^{16} \\
(1989)\end{array}$ & NA & FBT & Orthopedic surgeons & $10-15$ & NA & On cases only & $\begin{array}{c}4,907 \\
(3,649 / 1,258)\end{array}$ & No \\
\hline $\begin{array}{l}\text { 17. Riyadh/Saudi } \\
\text { Arabia }^{17} \\
(1994)\end{array}$ & No & FBT & $\begin{array}{l}\text { Nurses, a social } \\
\text { worker }\end{array}$ & $10-17$ & 1990-1991 & None & $\begin{array}{c}4,018 \\
\text { (girls only) }\end{array}$ & Yes \\
\hline $\begin{array}{l}\text { 18. Herning/Denmark } \\
\text { (1994) }\end{array}$ & No & FBT, Moiré & $\begin{array}{l}\text { Specialist in } \\
\text { orthopedic surgery }\end{array}$ & $10-17$ & 1981 & On cases only & $\begin{array}{c}989 \\
\text { (girls only) }\end{array}$ & No \\
\hline $\begin{array}{l}\text { 19. Dublin/US }{ }^{19} \\
(1995)\end{array}$ & No & $\begin{array}{l}\text { FBT and } \\
\text { Premenarchal } \\
\text { ATR }(\text { thoracic }) \geq 8^{\circ} \\
\text { or ATR }(\text { loin }) \geq 10^{\circ} \\
\text { Postmenarchal } \\
\text { ATR }(\text { thoracic }) \geq 10^{\circ} \\
\text { or ATR }(\text { loin }) \geq 15^{\circ}\end{array}$ & $\begin{array}{l}\text { A physician, a } \\
\text { physical education } \\
\text { teacher, a school } \\
\text { nurse }\end{array}$ & $10-14$ & $1986-1987$ & 3 years & $\begin{array}{c}8,686 \\
\text { (girls only) }\end{array}$ & No \\
\hline
\end{tabular}


Table 1. Characteristics of school scoliosis screening programs (cont)*

\begin{tabular}{|c|c|c|c|c|c|c|c|c|}
\hline $\begin{array}{l}\text { 20. Shanxi/China }{ }^{20} \\
(1995)\end{array}$ & No & $\mathrm{FBT} / \mathrm{ATR} \geq 4^{\circ}$ & $\begin{array}{l}\text { Physicians, nurses, } \\
\text { medical students }\end{array}$ & $7-18$ & $1992-1993$ & None & $\begin{array}{c}24,130 \\
(11,583 / 12,547)\end{array}$ & Yes \\
\hline $\begin{array}{l}\text { 21. Galilee/Israel }{ }^{21} \\
(1996)\end{array}$ & NA & FBT & $\begin{array}{l}\text { Trained person, } \\
\text { orthopedist }\end{array}$ & $9-13$ & NA & None & $\begin{array}{c}2,940 \\
(1,733 / 1,207) \\
\end{array}$ & No \\
\hline $\begin{array}{l}\text { 22. } \text { Central } \\
\text { Netherlands }{ }^{22} \\
(1996)\end{array}$ & Yes & $\begin{array}{l}\text { FBT, rib hump height, } \\
\text { ATR } \geq 5^{\circ}, \text { Moiré } \geq 2 \\
\text { lines }\end{array}$ & $\begin{array}{l}\text { Trained physicians, } \\
\text { an orthopedist }\end{array}$ & $10,12,14$ & 1983-1984 & 3 years & 30,611 & Yes \\
\hline $\begin{array}{l}\text { 23. Leeds/England }{ }^{23} \\
(1996)\end{array}$ & No & $\mathrm{FBT} / \mathrm{ATR} \geq 5^{\circ}$ & $\begin{array}{l}\text { Trained research } \\
\text { nurses }\end{array}$ & $6-14$ & NA & None & $\begin{array}{c}15,799 \\
(8,186 / 7,613) \\
\end{array}$ & No opinion \\
\hline $\begin{array}{l}\text { 24. Sofia/Bulgaria }{ }^{24} \\
(1996)\end{array}$ & No & FBT & Orthopedic surgeons & $11-15$ & 1995-1996 & None & 4,800 & Yes \\
\hline $\begin{array}{l}\text { 25. Beijing/China }{ }^{25} \\
(1996)\end{array}$ & No & $\mathrm{FBT} / \mathrm{ATR} \geq 5^{\circ}$ & Physicians & $8-14$ & 1986 & None & 21,759 & Yes \\
\hline $\begin{array}{l}\text { 26. Ankara/Turkey }{ }^{26} \\
\text { (1997) }\end{array}$ & No & FBT & $\begin{array}{l}\text { Residents in physical } \\
\text { medicine \& } \\
\text { rehabilitation }\end{array}$ & $6-13$ & 1994-1995 & None & $\begin{array}{c}4,682 \\
(2,466 / 2,216)\end{array}$ & Yes \\
\hline $\begin{array}{l}\text { 27. Crete/Greece }{ }^{27} \\
(1997)\end{array}$ & Yes & FBT & $\begin{array}{l}\text { General } \\
\text { practitioners, } \\
\text { physicians, nurses }\end{array}$ & $6-12$ & 1990-1992 & $\begin{array}{l}\text { On cases only } \\
(6-12 \text { months })\end{array}$ & $\begin{array}{c}21,220 \\
(10,942 / 10,278)\end{array}$ & No opinion \\
\hline $\begin{array}{l}\text { 28. Northwestern and } \\
\text { Central Greece } \\
\text { (1997) }\end{array}$ & No & FBT & $\begin{array}{l}\text { Orthopedic residents, } \\
\text { medical students, } \\
\text { senior orthopedic } \\
\text { surgeons }\end{array}$ & $9-14$ & 1993-1994 & None & $\begin{array}{c}82,901 \\
(41,939 / 40,962)\end{array}$ & Yes \\
\hline $\begin{array}{l}\text { 29. Kagawa/Japan }{ }^{29} \\
\text { (1999) }\end{array}$ & No & FBT & Physical therapist & NA & 1997 & None & 468 & Yes \\
\hline
\end{tabular}


Table 1. Characteristics of school scoliosis screening programs (cont)*

\begin{tabular}{|c|c|c|c|c|c|c|c|c|}
\hline $\begin{array}{l}\text { 30. } \text { Japan }^{30} \\
(1999)\end{array}$ & Yes & $\begin{array}{l}\text { Moiré } \geq 5 \mathrm{~mm}, \\
\text { Low-dose } \\
\text { roentgenography }\end{array}$ & $\begin{array}{l}\text { Objectively } \\
\text { measured (screeners } \\
\text { not mentioned) }\end{array}$ & $10-13$ & 1997 & None & $\begin{array}{c}56,788 \\
(28362 / 28426)\end{array}$ & Yes \\
\hline $\begin{array}{l}\text { 31. } \text { Spain }^{31} \\
\text { (1999) }\end{array}$ & No & FBT & Pediatrician & $10-15$ & NA & On cases only & $\begin{array}{c}161 \\
(92 / 69)\end{array}$ & No \\
\hline $\begin{array}{l}\text { 32. Rochester/US }{ }^{32} \\
\text { (1999) }\end{array}$ & Yes & $\begin{array}{l}\text { FBT/ATR } \geq 7^{\circ} \\
\text { (yearly in Grade 5-9) }\end{array}$ & $\begin{array}{l}\text { Public health nurses } \\
\text { supervised by an } \\
\text { orthopedic surgeon }\end{array}$ & $8-19$ & 1984-1989 & $\begin{array}{l}\text { Up to age } 19 \\
\text { years }\end{array}$ & 2,242 & No opinion \\
\hline $\begin{array}{l}\text { 33. Thriasio/Greece }{ }^{33} \\
(2002)\end{array}$ & No & $\mathrm{FBT} / \mathrm{ATR} \geq 7^{\circ}$ & NA & $5.5-17.5$ & 1977-1999 & On cases only & $\begin{array}{c}3,039 \\
(1,506 / 1,533)\end{array}$ & Yes \\
\hline $\begin{array}{l}\text { 34. } \text { Israel }^{34} \\
(2002)\end{array}$ & Yes & FBT & Trained pediatrician & $12-18$ & 5 year & On cases only & $\begin{array}{c}2,380 \\
(1,142 / 1,238) \\
\end{array}$ & Yes \\
\hline $\begin{array}{l}\text { 35. Columbia/ } \mathrm{US}^{35} \\
(2002)\end{array}$ & Yes & FBT & School nurses & NA & 1989-1996 & $\begin{array}{l}\text { Varied from } \\
\text { none to } 1 \text { year }\end{array}$ & 52,300 & No opinion \\
\hline $\begin{array}{l}\text { 36. } \text { Singapore }^{36} \\
(2005)\end{array}$ & Yes & $\mathrm{FBT} / \mathrm{ATR} \geq 5^{\circ}$ & $\begin{array}{l}\text { Experienced } \\
\text { registered nurses, } \\
\text { medical officers }\end{array}$ & $6-14$ & 1997 & None & $\begin{array}{c}72,699 \\
(35,558 / 37,141)\end{array}$ & Yes \\
\hline
\end{tabular}

$*$ ATR $=$ Angle of trunk rotation; FBT $=$ Forward bending test; NA = Details not available

†Estimated figures 
Table 2. Pooled estimates and multivariable meta-regression

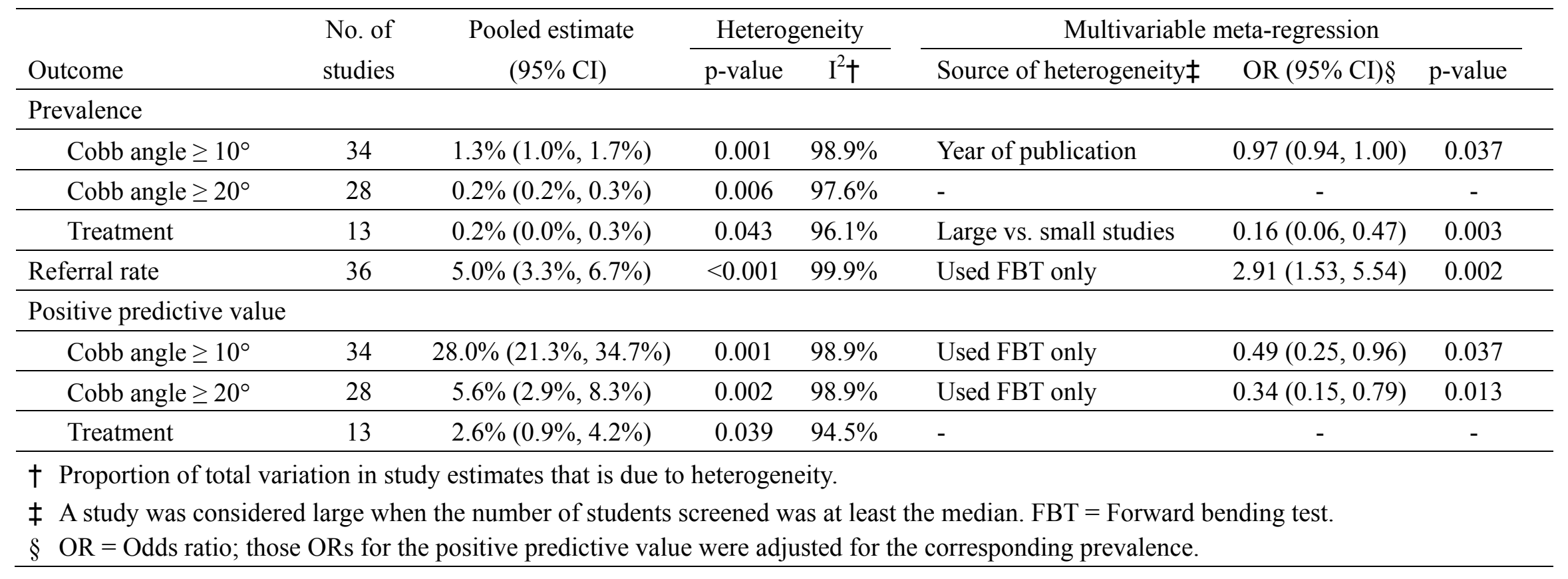




\section{Figure Legends}

Figure 1. Pooled estimate of prevalence of adolescent idiopathic scoliosis

(a) with a Cobb angle of at least $10^{\circ}$

(b) with a Cobb angle of at least $20^{\circ}$

(c) with treatment

Figure 2. Pooled estimate of referral rate for radiography

Figure 3. Pooled estimates of positive predictive values

(a) for a Cobb angle of at least $10^{\circ}$

(b) for a Cobb angle of at least $20^{\circ}$

(c) for treatment 


\section{Figure 1a}

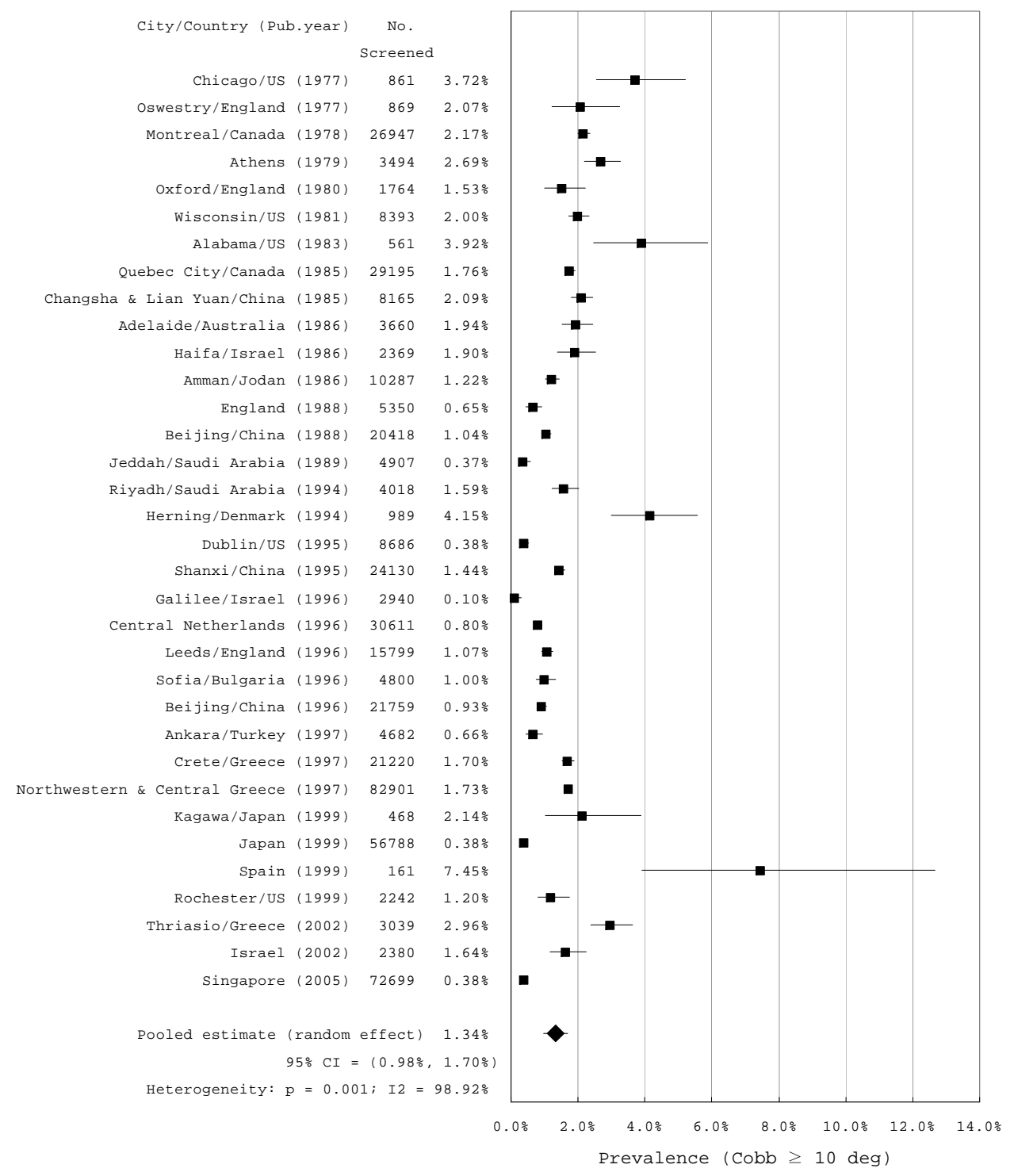




\section{Figure $1 b$}

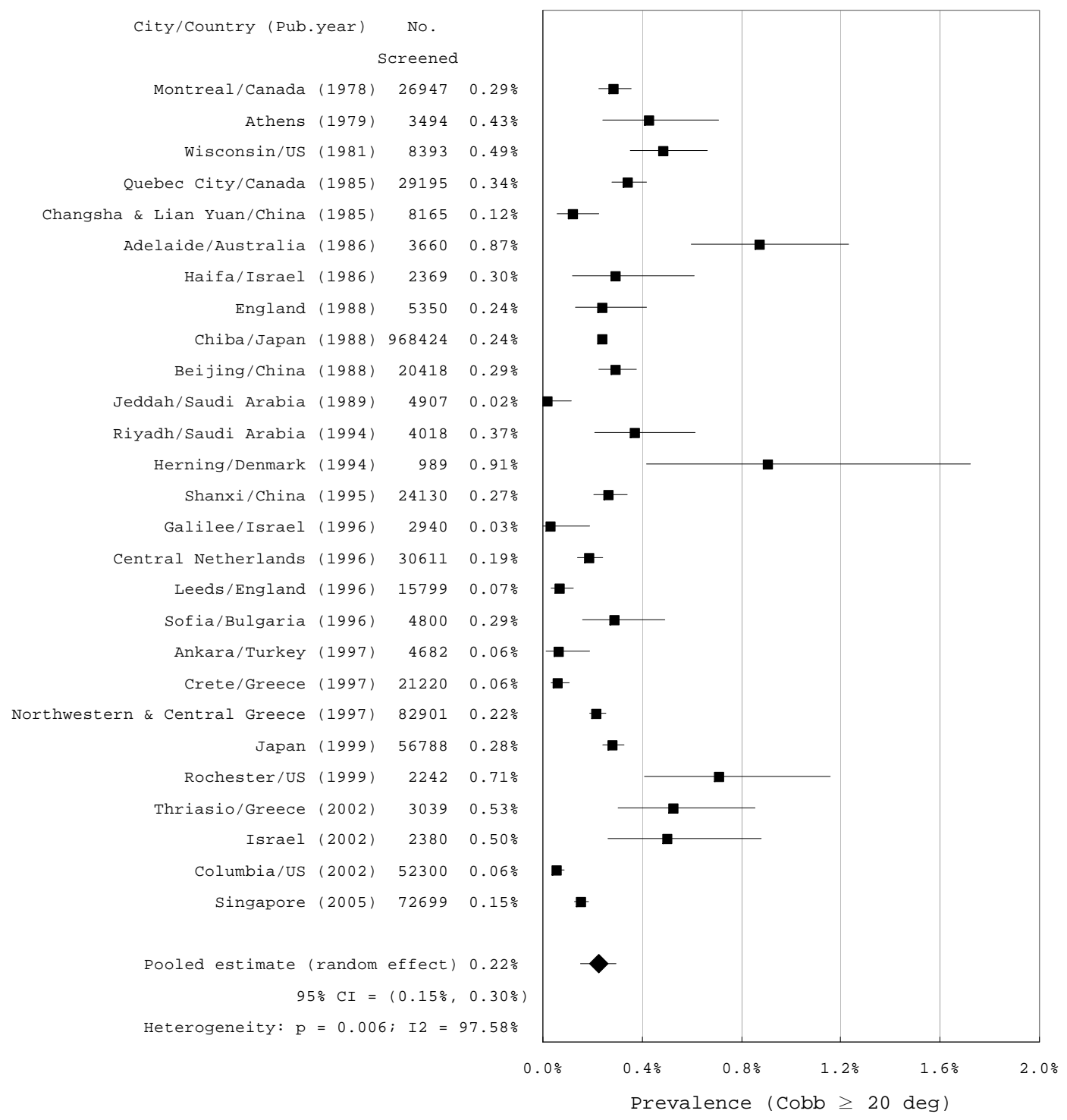


Figure 1c

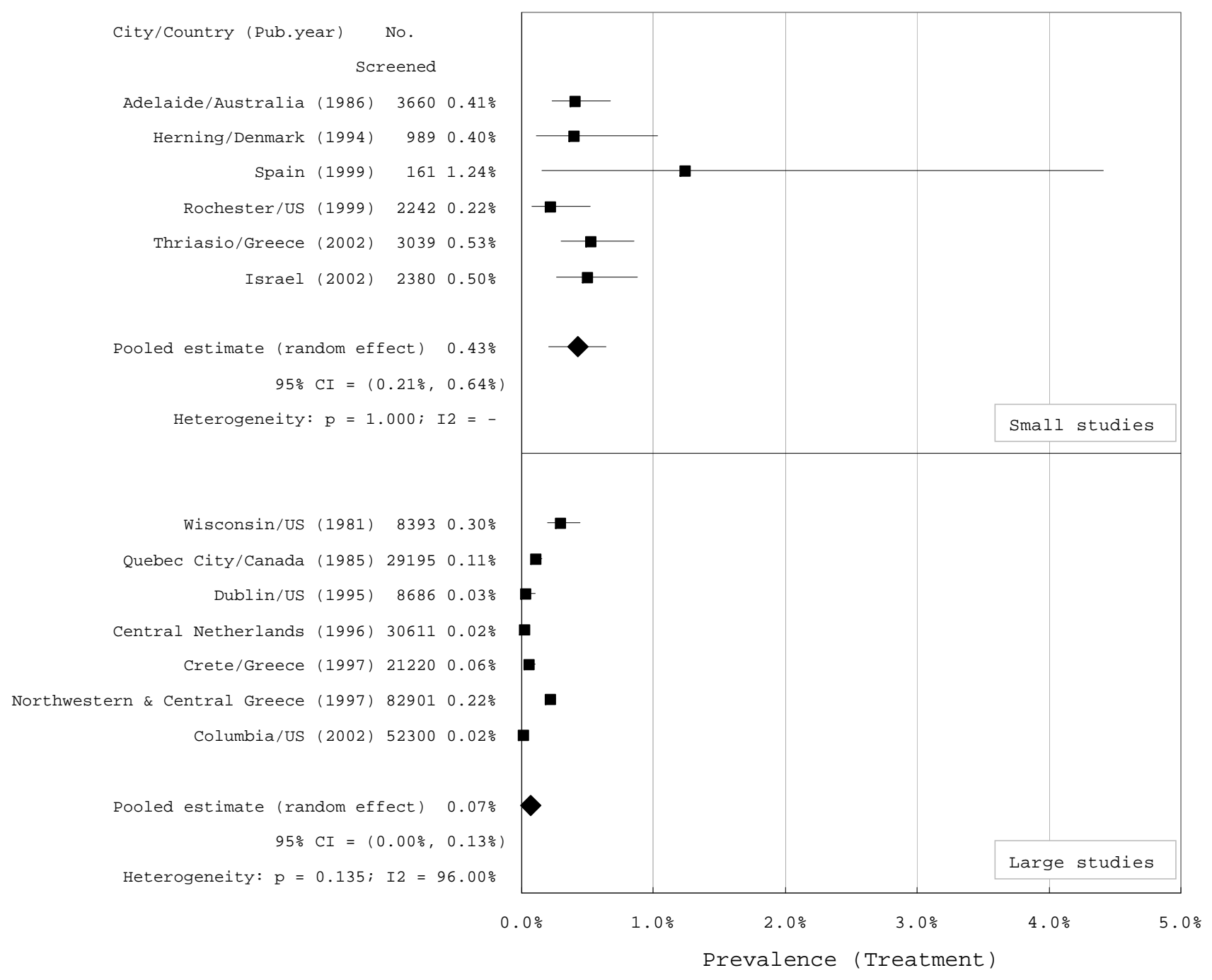


Figure 2

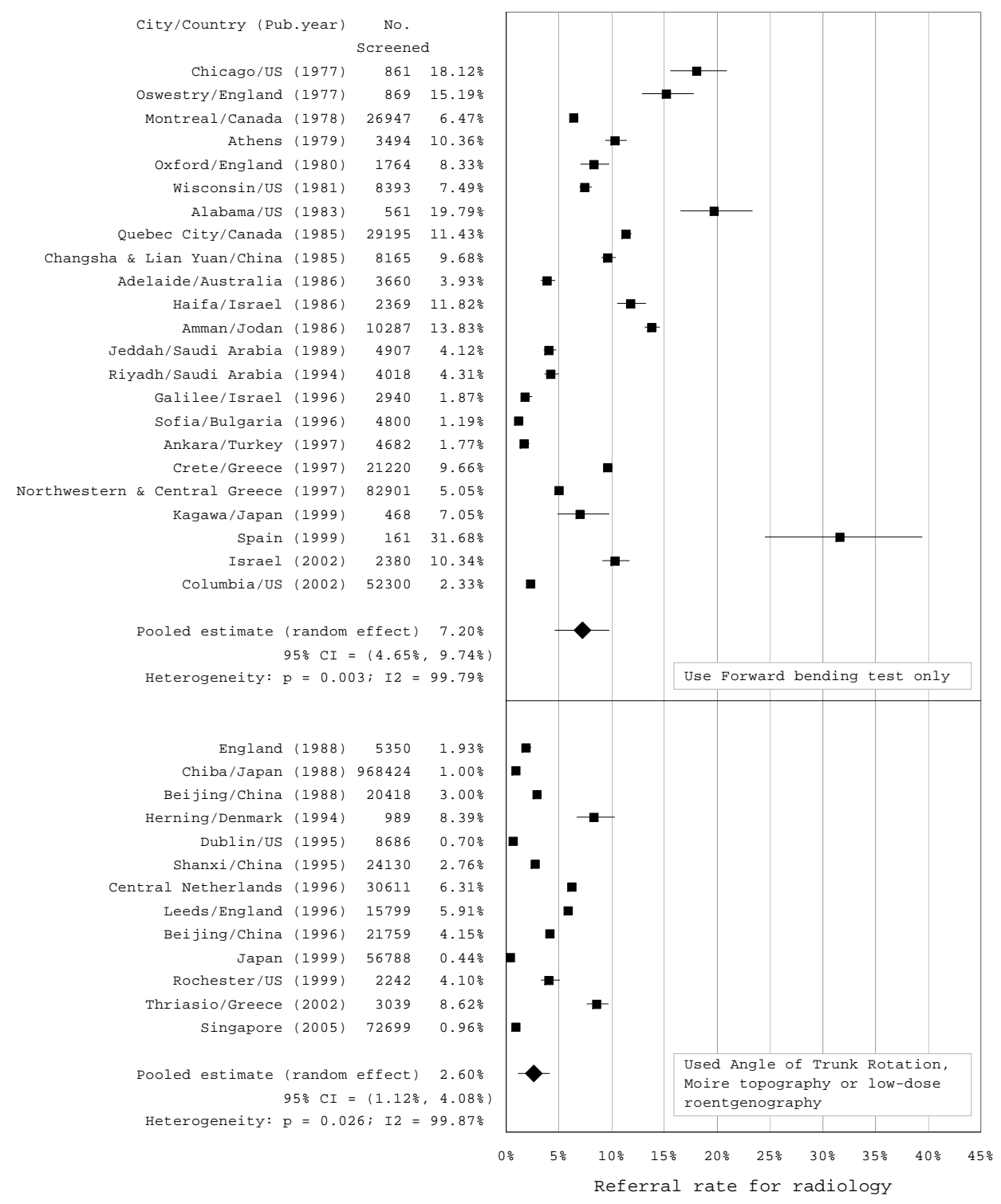




\section{Figure 3a}

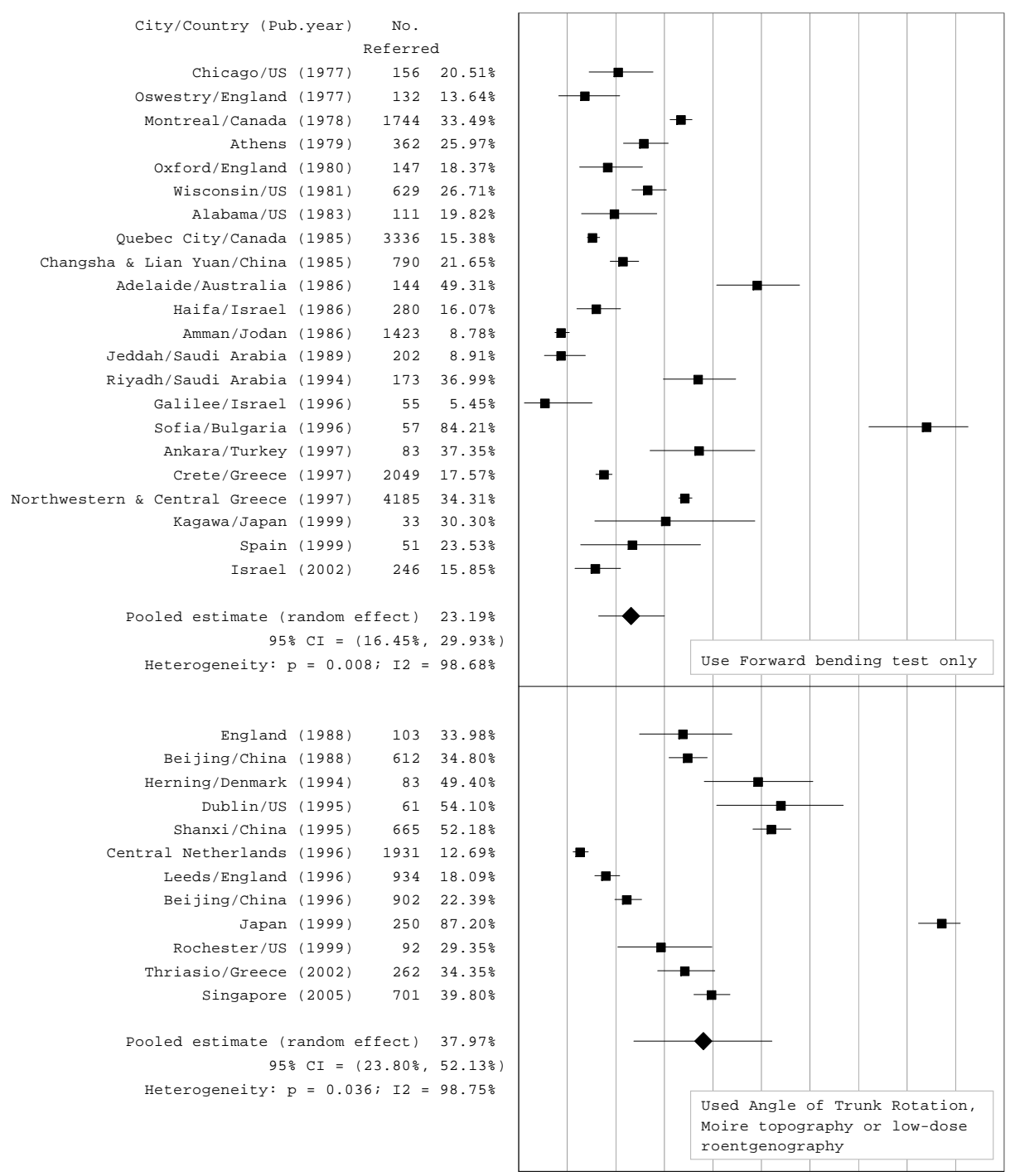

$\begin{array}{lllllllllll}0 \% & 10 \% & 20 \% & 30 \% & 40 \% & 50 \% & 60 \% & 70 \% & 80 \% & 90 \% & 100 \%\end{array}$ Positive Predictive Value (Cobb $\geq 10 \mathrm{deg}$ ) 


\section{Figure $3 b$}

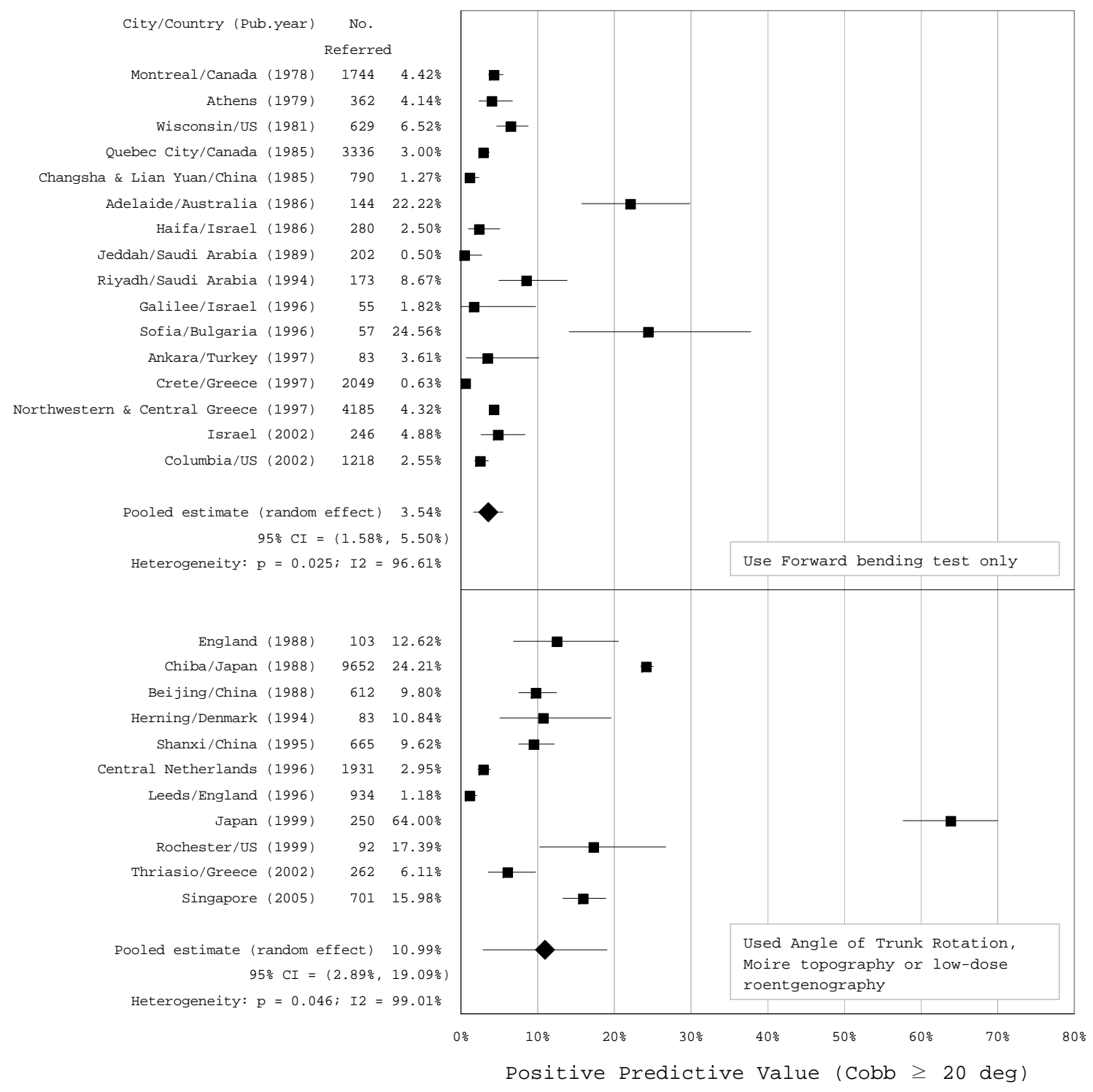




\section{Figure 3c}

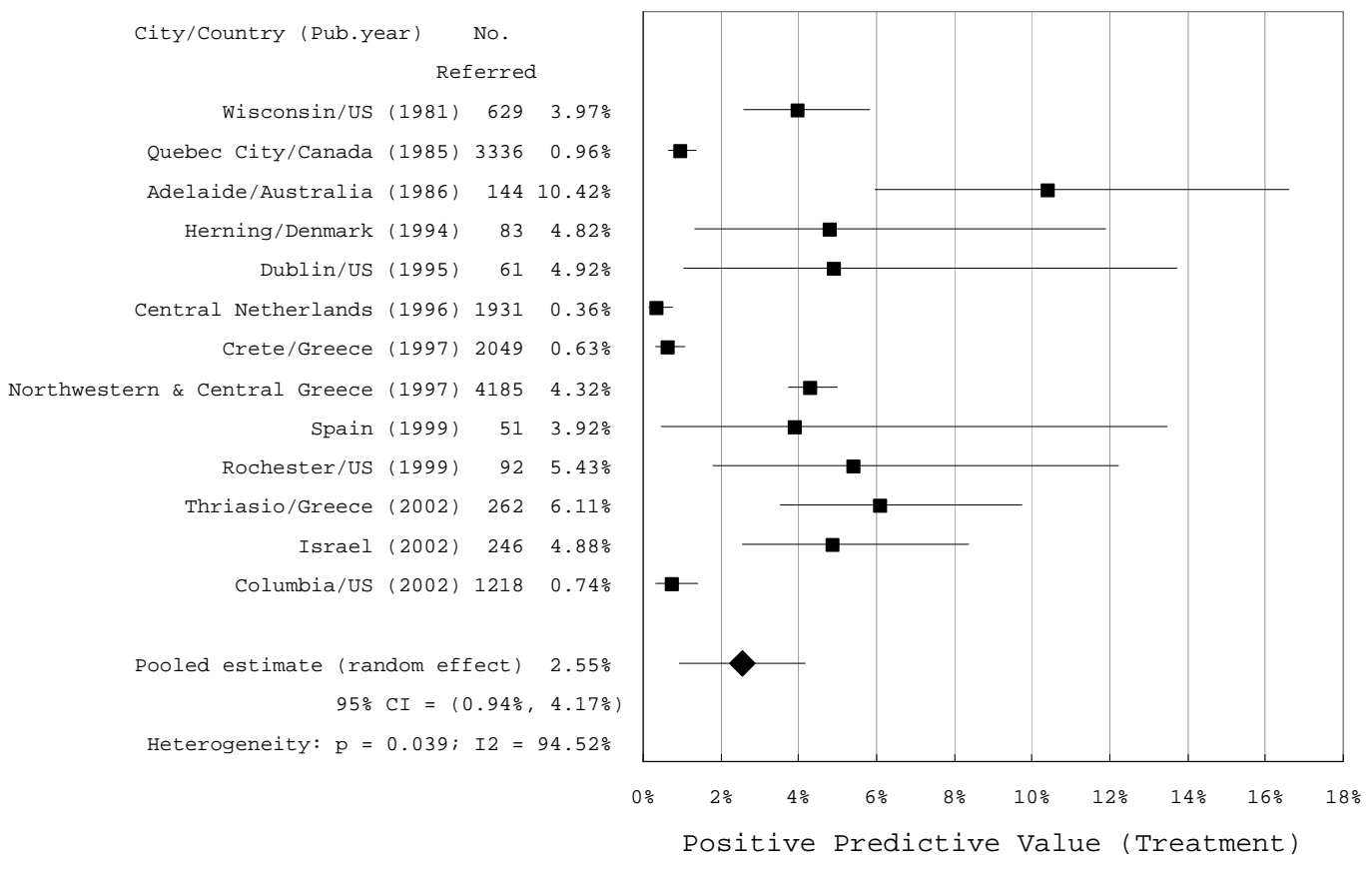

